\title{
Sludge water stabilization treatment
}

\author{
Elena Murko ${ }^{1}$, $^{*}$, Vasily Murko ${ }^{3}$, and Jurgen Kretchmann ${ }^{4}$
}

${ }^{1}$ T.F. Gorbachev Kuzbass State Technical University, 650000 Kemerovo, 28 Vesennyaya st., Russian Federation

${ }^{2}$ Prokopyevsk branch of T.F. Gorbachev Kuzbass State Technical University, 650036

Prokopyevsk, 19 Nogradskaya st., Russian Federation

${ }^{3}$ Sibniiugleobogaschenie LLC, Branch of Prokopyevsk, 653000 Prokopyevsk, 1 Gornaya

st., Russian Federation

${ }^{4}$ Technische Hochschule Georg Agricola (THGA), 44787, Herner Str. 45, Bochum, Germany

\begin{abstract}
Technologically contaminated water, formed during processing of coal slurries, finds its application in modern technological cycles of coal enrichment. Limitation of use of untreated recycled water of coal concentration plants is caused by a high degree of its mineralization by various salts, presence of insoluble solid particles and presence of flotation reagents, coagulants and flocculants. Part of technical water purified from mineral and organic contaminants can be used in heating systems and heat exchange equipment of industrial enterprises, including the coal industry. For this purpose, it is necessary to reduce the scale-forming ability of service water (to reduce the content of soluble calcium and magnesium salts in water). One of the most effective and advanced methods is the stabilization treatment of water with an electric field. In addition, this method is environmentally safe, low-cost and simple. The article gives the foundation of the method of stabilization treatment of recycled water of concentrating plants by an electric field, a description of the methodology of the laboratory experiment for scaling reduction, and the analysis of the results.
\end{abstract}

\section{Introduction}

The main disadvantage of coal concentration plants, which has a negative environmental impact, is the discharge of sludge water into external settling ponds. In order to significantly reduce the negative impact of coal concentration plants on the environment, it is necessary to create closed water cycles at these enterprises [1-6].

Preliminary treatment of industrial wastewater from mining enterprises is mainly aimed at cleaning them from suspended solids, especially with the use of technogenic filter massifs from overburden rock [7-14]. The use of geotextile materials for dewatering of water-coal

\footnotetext{
* Corresponding author: zhev.httte@,kuzstu.ru
} 
slurry makes sense at further purification of sludge water released from the surface of shell filtering constructions [15-17].

The applied staged schemes of sludge water treatment should provide the maximum use of treated water in the main technological processes. The first stage is the separation of sludge water into a solid phase (slurry) and a liquid phase (process water) [18-21]. Then process water undergoes the following stages of treatment: settling, clarification and filtration. Deep mechanical treatment of technological water from flocculants and flotation agents is realized with the use of appropriate sorbents. Passing these stages of treatment allows for removal of suspended mineral particles and organic ones. Sludge water purified from suspended solids, organic impurities and hardness salts can be used in heat supply systems of coal concentration plants. For this purpose, it is necessary to reduce scale-forming ability of sludge water, caused by the presence of hardness salts in it.

\section{Materials and Methods}

The research on the influence of sludge water treatment by electric field was carried out in a cylindrical cell. Metal cathode and graphite anode embedded in this cell had surface areas of $2 \cdot 10^{-3} \mathrm{~m}^{2}$ and $1 \cdot 10^{-3} \mathrm{~m}^{2}$ correspondingly, i.e. surface area of the cathode was 2 times larger than that of the anode. Consequently, the current density at the anode was 2 times higher than the current density at the cathode.

The research was carried out on the laboratory unit, the scheme of which is shown in Fig. 1.

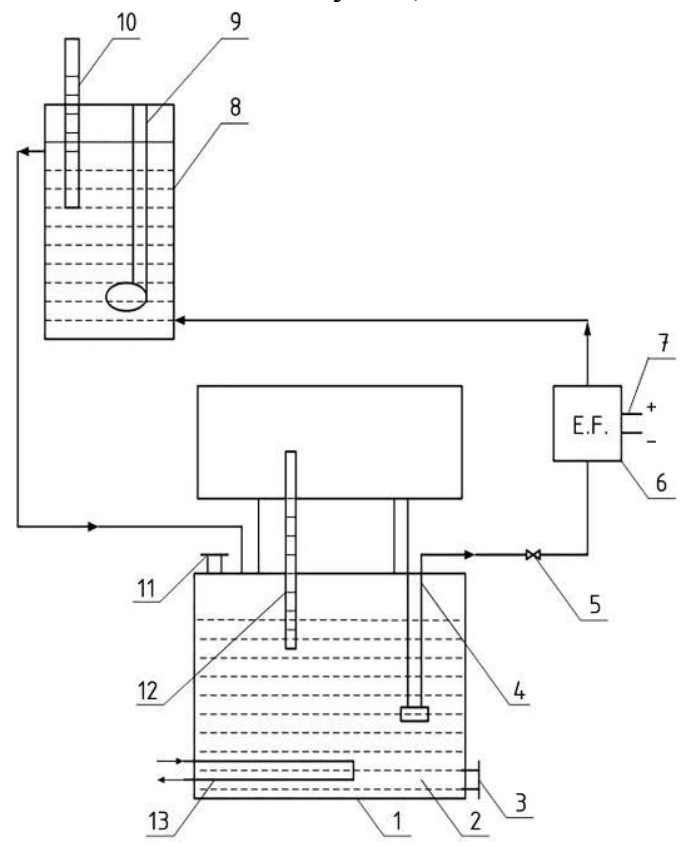

Fig. 1. Schematic diagram of laboratory unit for stabilizing treatment of sludge water by electric field:

1 - thermostat; 2 - test water; 3,11 - sockets for water supply and withdrawal respectively; 4 - pump; 5 - valve; 6 - apparatus for processing of sludge water by electric field; 7 source of direct current; 8 - heating cell; 9 - heating element; 10,12 - thermometers; 13 U-shaped tube for cooling water.

From thermostat 1 studied slurry water 2 was pumped into the heating cell 8 , in which an electric heating element 9 and thermometer 10 were built in. Before the heating cell, the 
analyzed slurry water passed through the apparatus 6 , in which it was treated by an electric field. From the heating cell 8 the hot slurry water flowed back to the thermostat 1 .

The sludge water temperature before entering the heating cell was maintained within the range of $60-65^{\circ} \mathrm{C}$ by cooling it in the thermostat with cold water flowing through the U-shaped tube 13 . The temperature of the slurry water at the outlet of the heating cell was determined by the thermometer 10 and maintained within $92-95^{\circ} \mathrm{C}$ by controlling the voltage applied to the heating element 10 . The surface of the heating element was $5,6 \cdot 10^{-3}$ $\mathrm{m}^{2}$.

Sludge water stabilization treatment by electric field was carried out in a sealed cell, in which metal cathode, graphite anode and water inlet and outlet connections were built in. Electric current from a direct current source was applied to the cathode and anode. Thus, a constant electric field was created between the anode and the cathode.

The analyzed slurry water passing between the anode and the cathode was exposed to an electric field, as a result of which the particles of scaling agents present in the water acquired a positive charge, moved to the metal cathode and deposited on its surface in the form of a scaling layer.

The amount of scale formed on the surface of the heating element was determined as follows. The heating element was weighed after certain time intervals of the installation operation and the mass of the heating element of two consecutive measurements was determined by the difference of the mass of the heating element.

The efficiency of the heating element protection against scaling (scale-proof effect) when treating sludge water with an electric field was determined by the formulae:

$$
E=\frac{m_{b}-m_{o}}{m_{b}} \cdot 100 \%,
$$

where $m_{b}$ - mass of scale deposited on the heating element in sludge water not treated by electric field; $m_{o}$ - mass of scale deposited on the heating element in sludge water treated by electric field.

The researches were carried out in the closed operation mode of the unit, i.e. without feeding of the system with fresh sludge water. Sludge water treatment by electric field was carried out at different values of current densities on cathodes and anodes. In order to find out the scale-proof effect of sludge water treatment by electric field a control experiment was carried out first. The dynamics of scale deposition on a heating element was determined in conditions of absence of electric field. Conditions of experiments are presented in Table 1. Experiments were carried out on the sludge water of enrichment plant "Berezovskaya". The main characteristics of this water are presented in Table 2.

Table 1. Conditions of experiments.

\begin{tabular}{|c|c|c|}
\hline Condition name & $\begin{array}{c}\text { Unit of } \\
\text { measurement }\end{array}$ & $\begin{array}{c}\text { Measurement value } \\
\text { parameters }\end{array}$ \\
\hline Volume of water in the system & $\mathrm{m}^{3} \cdot 10^{-3}$ & 5.1 \\
\hline $\begin{array}{c}\text { Water velocity, flowing through the heating } \\
\text { element }\end{array}$ & $\mathrm{m} / \mathrm{sec}$ & 0.3 \\
\hline Density of cathode current & $\mathrm{A} / \mathrm{m}^{2}$ & $3.5-14$ \\
\hline Anode current density & $\mathrm{A} / \mathrm{m}^{2}$ & $7-28$ \\
\hline
\end{tabular}


Table 2. Main characteristics of the quality of analyzed slurry water.

\begin{tabular}{|c|c|c|}
\hline Description of characteristics & $\begin{array}{c}\text { Unit of } \\
\text { measurement }\end{array}$ & $\begin{array}{c}\text { Measurement } \\
\text { value } \\
\text { parameters }\end{array}$ \\
\hline $\mathrm{pH}$ & & 8.27 \\
\hline Dry residue & $\mathrm{mg} / 1$ & 430 \\
\hline Chemical quality index & $\mathrm{mg} \mathrm{O} / 1$ & 6.8 \\
\hline Total hardness & $\mathrm{mmol} / 1$ & 2.8 \\
\hline Calcium ion content & $\mathrm{mmol} / 1$ & 1.9 \\
\hline Magnesium ion content & $\mathrm{mmol} / 1$ & 0.9 \\
\hline
\end{tabular}

The experiments were carried out at the rate of flow of slurry water through the heating cell equal to $0.3 \mathrm{~m} / \mathrm{s}$. First, experiments were carried out on water not treated by the electric field (control experiment), and then on water treated by the electric field. The cathodic and anodic current densities varied from 3.5 to $14 \mathrm{~A} / \mathrm{m}^{2}$ and from 7 to $28 \mathrm{~A} / \mathrm{m}^{2}$, respectively.

\section{Results and Discussion}

Experimental results of sludge water treatment by electric field at different values of current densities on cathodes and anodes are presented in Table 3.

Table 3. Dynamics of scale deposition on heating element $\left(\mathrm{kg} \cdot 10^{-3}\right)$ at electric field treatment of sludge water in the closed systems.

\begin{tabular}{|c|c|c|c|c|}
\hline \multirow{2}{*}{$\begin{array}{c}\text { Operating } \\
\text { time, hours }\end{array}$} & \multirow{2}{*}{$\begin{array}{c}\text { Without electric } \\
\text { field treatment }\end{array}$} & \multicolumn{3}{|c|}{ With electric field treatment } \\
\cline { 3 - 5 } & $\mathbf{I a}^{*}=\mathbf{7 ,} \mathbf{I c}=\mathbf{3 . 5}$ & $\mathbf{I a}=\mathbf{1 4}, \mathbf{I c}=\mathbf{7}$ & $\begin{array}{c}\mathbf{I a}=\mathbf{2 8} \\
\mathbf{I c}=\mathbf{1 4}\end{array}$ \\
\hline 1 & 0.031 & 0.029 & 0.027 & 0.025 \\
\hline 2 & 0.094 & 0.058 & 0.053 & 0.039 \\
\hline 3 & 0.143 & 0.086 & 0.068 & 0.055 \\
\hline 4 & 0.197 & 0.107 & 0.077 & 0.062 \\
\hline 5 & 0.212 & 0.120 & 0.088 & 0.064 \\
\hline
\end{tabular}

* Ia, Ic - current densities on anodes and cathodes, $\mathrm{A} / \mathrm{m}^{2}$, respectively

According to the experimental data obtained, curves of scaling on the heating element during the treatment of water by electric field in closed systems at different values of current density were calculated. These curves are shown in Fig. 2. 


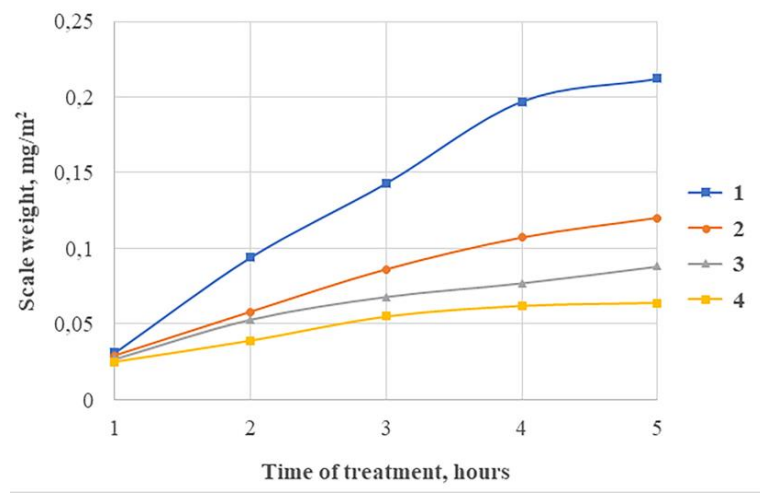

Fig. 2. Dependence of scale formation on a heating element on time at treatment of sludge water by electric field in closed systems: 1 - without sludge water treatment by electric field (control experiment); 2, 3, 4-with sludge water treatment by electric field at cathode current density 3,$5 ; 7$ and $14 \mathrm{~A} / \mathrm{m}^{2}$ and anode current density $7 ; 14$ and $28 \mathrm{~A} / \mathrm{m}^{2}$ respectively.

On the basis of experimental data according to the formula (1) the efficiency of scale protection of the heating element was calculated when treating sludge water by the electric field in a closed operation mode of the laboratory unit. The obtained results are presented in table 4 and fig. 3.

Table 4. Scale protection effectiveness of the heating element when treating slurry water with an electric field in closed systems.

\begin{tabular}{|c|c|c|c|}
\hline $\begin{array}{c}\text { Unit operating time, } \\
\text { hours }\end{array}$ & $\mathbf{I a}=\mathbf{7 ,} \mathbf{I c}=\mathbf{3 . 5}$ & $\mathbf{I a}=\mathbf{1 4}, \mathbf{I c}=\mathbf{7}$ & $\mathbf{I a}=\mathbf{2 8 ,} \mathbf{I c}=\mathbf{1 4}$ \\
\hline 1 & 6.45 & 12.90 & 19.35 \\
\hline 2 & 38.29 & 43.61 & 58.51 \\
\hline 3 & 39.86 & 45.68 & 61.53 \\
\hline 4 & 42.28 & 52.44 & 68.52 \\
\hline 5 & 43.39 & 58.49 & 69.81 \\
\hline
\end{tabular}

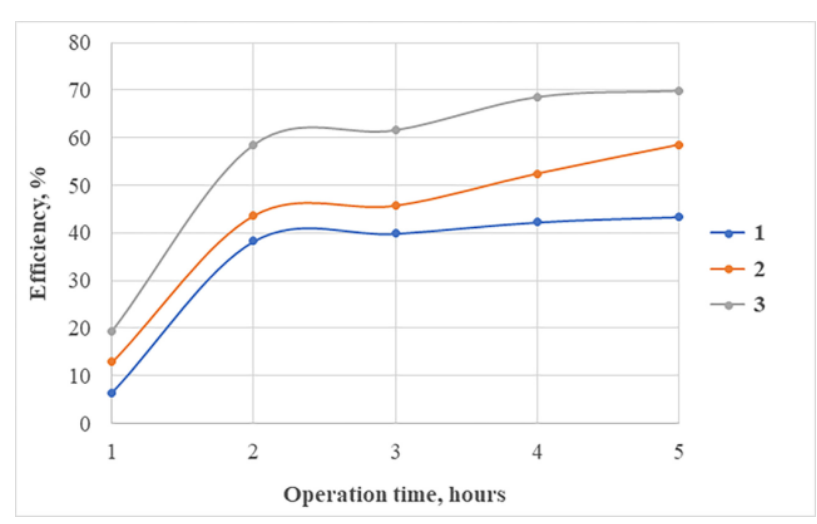

Fig. 3. Dependence of the antiscale protection efficiency on the current density at electric treatment of sludge water: $1,2,3$ - cathode current density 3,$5 ; 7 ; 14 \mathrm{~A} / \mathrm{m}^{2}$ and anode current density $7 ; 14$ and $28 \mathrm{~A} / \mathrm{m}^{2}$ respectively. 
From the data presented in Table 4 and Fig. 3, we can see that the efficiency of protection of water-heating equipment against scale during stabilization treatment of sludge water by electric field depends on the values of anode and cathode current densities. At increase of values of anode and cathode currents efficiency of antiscale protection increases. Data of Table 4 show that at increase of unit operation time the antiscale effect of sludge water treatment by electric field sharply increases in the first two hours, and continues to increase insignificantly in the subsequent time. This is explained by the fact that sludge water in the system is subjected to repeated antiscale treatment by electric field for a longer period of time. Also, the main mass of hardness salts is deposited on the cathode in the first hours of sludge water treatment by electric current.

\section{Conclusions}

The most environmentally safe and quite effective method of sludge water antiscale treatment is an electric field treatment. This method excludes the use of chemicals and, as a consequence, pollution of the environment by harmful effluents of water treatment plants. The efficiency of this method is confirmed by obtained experimental data and reaches $70 \%$. Application of sludge water stabilization treatment in heat supply systems of coal preparation plants will allow:

a) reduce the discharge of harmful wastewater into natural water reservoirs and thereby improve the environmental safety of coal concentration plants;

b) increase the service life of water-heating equipment by 1.3-1.5 times;

c) increase the economic efficiency of enterprises;

d) create a technology for complex processing of sludge water.

\section{References}

1. K.V. Thambimuthu, N. S. H. Stover N.S.H., N. Whaley, JchemE Symposium series, 107, 133 (1987)

2. H. Atlas, E. Z. Casassa, G. D. Parfitt, A. S. Rao, E. W. Toor, 10-th Annual Powder and Bulk Solids conf. (1985)

3. O. Schwarz, Brennst - Kraft, 16, 273 (1964)

4. O. Schwarz, Das Entwicklugsvorhaben «Director Verbrennung von Kohle-Wasser Suspension in Kraftwerken» (Electrizi - tatwirstchaft, 1966)

5. R. D. Glenn, Coal slurry applications and technology (EPRJ GS-7209, Palo Alto, CA, USA, Electric Power Research Institute, 1991)

6. P. Legar, Tech Sci Meth, 6, 253 (1987)

7. Y. Lesin , V. Gogolin, E. Murko, S. Markov, J. Kretschmann, E3S Web of Conf., 41, 01039 (2018)

8. M. Tyulenev, Yu. Lesin, E. Tyuleneva, E. Murko, E3S Web of Conf., 15, 02003 (2017)

9. E. V. Makridin, M. A. Tyulenev, S. O. Markov, Y. V. Lesin, E. V. Murko, Mining Inf and Analytical Bulletin, 12, 89 (2020)

10. Tyulenev, M., Markov, S., Makridin, E., Lesin, Y., Gogolin, V., E3S Web of Conf., 105, 02022 (2019)

11. M. Tyulenev, A. Khoreshok, E. Garina, O. Litvin, Y. Litvin, E. Maliukhina, IOP Conference Series: Earth and Environmental Science, 012035 (2017)

12. M. V. Griyzev, N. M. Kachurin, G. V. Stas, Sustainable development of mountain territories, 10(1), 141 (2018)

13. M. Tyulenev, Yu. Lesin, O. Litvin, E. Maliukhina, A. Abay, E3S Web of Conf., 21, 02019 (2017) 
14. S. Markov, V. Martyanov, E. Preis, A. Abay, E3S Web of Conf., 21, 01021 (2017) E. Makridin, S. Markov, E. Murko, Y. Lesin, M. Hellmer, E3S Web of Conf., 174, 01056 (2020)

15. V. A. Kalashnikov, A. V. Gorbachev, J. Min and Geotech Eng 3, 56 (2018)

16. E. Murko, V. Kalashnikov, A. Gorbachev, I. Mukhomedzyanov, E3S Web of Conf., 105, 02029 (2019)

17. O. O. Garshin, Z. A. Startseva, J. Min and Geotech Eng 2, 33 (2019)

18. I. Skoczko, E. Szatyłowicz, Proc 16(1), 3 (2019)

19. O. Lahav, L. Birnhack, Aquatic Chemistry (Walter de Gruyter GmbH, Berlin/Boston, 2019)

20. S. Sidney, P. Roque, A. Silvana, A. Alexandre, Water Sci Technol, 67 (5), 1017 (2013) 